\title{
HAGYOMÁNYOS ÉS REZGÉSCSILLAPÍTOTT „HOSSZÚ” FURAT ESZTERGAKÉSEK VISELKEDÉSEINEK ÖSSZEHASONLÍTÁSA
}

\author{
Wallyson Thomas Alves da Silva \\ PhD hallgató, Miskolci Egyetem, Szerszámgépészeti és Mechatronikai Intézet \\ Szerszámgépek Intézeti Tanszéke \\ 3515 Miskolc, Miskolc-Egyetemváros, e-mail: szmwally@uni-miskolc.hu \\ Fülöp Zsombor \\ PhD hallgató, Miskolci Egyetem, Szerszámgépészeti és Mechatronikai Intézet \\ Szerszámgépek Intézeti Tanszéke \\ 3515 Miskolc, Miskolc-Egyetemváros, e-mail: fulop.zsombor@uni-miskolc.hu
}

\begin{abstract}
Absztrakt
Cikkünk fó célja, hogy megvizsgáljuk a rezgéscsillapitott „hosszü” furat esztergakések viselkedését, amikor edzett acélt munkálunk meg. Mindemellett összehasonlitás történik a hagyományos „tömör” esztergakések és az elöbb emlitett csillapitott esztergakések forgácsleválasztás közbeni viselkedése között is. Ismeretes, hogy a szerszámgépek, azon belül a forgácsoló szerszámok esetén létrejövö káros rezgések a megmunkált felület minőségét meglehetösen rontják. Ennek kiküszöbölésére alkalmazzák az emlitett rezgéscsillapitott esztergakést, amelynek elönyeit kívánjuk bemutatni.
\end{abstract}

Kulcsszavak: impakt-rezgéscsillapitó, edzett acél, felületi minöség, szerszám élettartam

\begin{abstract}
The main objective of this paper is to evaluate the behaviour of the antivibrating internal turning tool with long overhangs, in the case of machining of hardened steel. Beside this, in this work there is a comparison of the behaviour between the aforementioned tools and the conventional "solid" turning tools as well. We are all know well that the existing deleterious vibrations of the machine tools, especially the vibrations of the tools fairly damage the quality of the machined surface. This mentioned antivibrating tool intend to eliminate these problems. We also wish to present the advantages of these tools.
\end{abstract}

Keywords: impact damper, hardened steel, surface quality, tool life

\section{Bevezetés, szakirodalom áttekintés}

Mély furatok belső megmunkálása, másnéven furatesztergálása meglehetősen nehéz feladat, amikor viszonylag hosszú és karcsú esztergakéssel kell dolgoznunk. A „túlnyúlást” mint paramétert/fogalmat a továbbiakban az esztergakés késtartón kívüli hosszának és ezen rész átméröjének hányadosával értelmezzük. Az ilyen hosszan túlnyúló furat esztergakések mechanikai rezgésre könnyedén hajlamosak, amelyek egyértelmủen a megmunkált felületi minőséget rontják [1]. Létezik azonban néhány csillapított esztergakés típus, amely többé-kevésbé megoldásként szolgálhat erre a problémára. Néhány közülük:

- Klasszikus rezgésfojtós megoldás (Damper Vibration Absorber - DVA) - amely áll egy késszárhoz adott rugó és tömeg alkotta rezgőrendszerből, amelyet mindig az adott forgácsolási 
feladatnak megfelelően, az adott struktúra sajátfrekvenciájára kell hangolnunk. Irodalmak szerint ezen megoldás nagyon hatékonyan müködik egészen 15-ös $L / D$ túlnyúlási értékig [1-2].

- Esztergakés viszkoelasztikus anyaggal - viszonylag könnyen alkalmazható mindenféle struktúra esetén [3]. Ilyen például a kereskedelmi forgalomban, gyártótól kapható „,csendes szerszám" (Silent Tool), amely egy nehézfémből készült cserélhető késfejből és szár részből áll, melynek belsejében gumirugót és csillapító folyadékot (olajat) is találhatunk [4].

- Esztergakés súrlódás elvén alapuló csillapítással (Friction Damper - FD) - ezen esztergakés szárának üregében találhatunk lemezeket, amelyek a súrlódás révén fejtik ki rezgéscsillapító hatásukat oly módon, hogy azok rezgés közben egymáshoz és az üreg falához dörzsölődnek [5].

- Ütközés elvén működő rezgéscsillapító - legtöbbször ezt az angol szakirodalomban Particle Impact Damper-ként emlegetik. Ez esetben a késszár üregében nagyságrendileg több száz fémből vagy kerámiából készült részecskét találhatunk. Ezek a részecskék, amelyek lehetnek kisméretű golyók is, rezgés közben az üreg falához ütköznek, így képesek disszipálni a rezgési energiát [6]. Ilyen típusú rezgéscsillapítással ellátott furat esztergakés metszetét láthatjuk az 1. ábrán [7]. Az ilyen szerszám erősen nemlineáris dinamikai viselkedést mutat, ami nagy nehézségeket okoz az optimális dinamikai paraméterek előzetes meghatározásánál. A késszárban lévő üreg a rúd merevségét csökkenti, viszont ennek ,helyére” kerülnek a részecskék nemlineáris csillapítási együtthatóinak problémái [8]. Többféle változat elképzelhető a részecskék alakjára, méretére, térkitöltésére vonatkozóan, melynek eredményeképpen nagymértékủ csillapítás érhető el széles frekvencia/ főorsó fordulatszám tartományban [9].

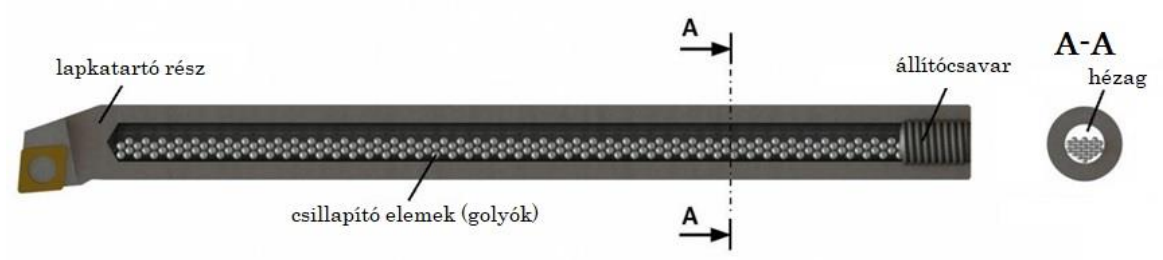

1. ábra. Furat esztergakés, ütközés elvén müködö rezgéscsillapitással [3]

\section{Eredmények}

Az összes furatesztergálási kísérletet CNC esztergán végeztük el, a föorsó maximális 4500-as percenkénti fordulatszáma mellett. Kétféle esztergakést alkalmaztunk munkánk a során: az első volt - amire már az előző fejezetben is utaltunk - a „tömör” szerszám, illetve késtartó, a második esetén pedig változatlan késtartóval, de üreges, golyókkal töltött késszár (Impact Damper - ID) került felhasználásra. Három különböző átmérőjủ golyót használtunk fel a kísérlet során, amelyek 5, 6,5 és $8 \mathrm{~mm}$-esek voltak. A szerszám rezgését egy piezoelektromos gyorsulásérzékelővel mértük, amelyet a szerszám éléhez közel ragasztottunk fel.

A kísérlet első szakaszánál célunk az volt, hogy felmérjük a két („tömör” és a már bemutatott, csillapított) késszár típus maximális túlnyúlásának lehetőségeit. Mértük a késszár rezgését edzett acél esztergálása közben, majd megmunkálást követően a megmunkált felületminőségét.

A 2. ábra a létrejött felületminőséget mutatja a különböző szerszám típusok és különböző $L / D$ túlnyúlási értékek függvényében. Tekintve a diagramot, az első dolog amit ki kell emelnünk, hogy a felületi minőség közel azonos lett a csillapított esztergakések használatánál, különösen ahol 6,5 és 8 $m m$ átméröjü golyókat használtunk fel, de látható az is, hogy mindegyik csillapított szerszámra létezik 
egy olyan túlnyúlási érték, amelynél a megmunkált felületi minőség drasztikusan romlik. A 0,8 -as $R a$ érték fölötti felületi érdesség értéke túl nagy ahhoz, hogy elfogadható legyen az edzett acél megmunkálása esetén (ez esetben a köszörülést kellene választanunk a furatmegmunkálás befejező műveleteként). Vegyük észre, hogy ezen túlnyúlási értékek változtatása csak néhány milliméteres változtatást jelentenek a szerszám hosszának tekintetében. Ez azt jelenti, hogy az ilyen szerszám dinamikailag rendkívül érzékennyé válhat; kis változtatás a szerszám merevségi paraméterén drasztikus változást okozhat a „túlnyúlási határ” kis környezetében. A következőkben tehát a szerszám maximális túlnyúlását, mint a szerszám „teljesítményét”, pontosabban dinamikailag stabil forgácsolási képességét kívánjuk előtérbe helyezni/vizsgálni különböző típusú szerszámok maximális túlnyúlása esetén.

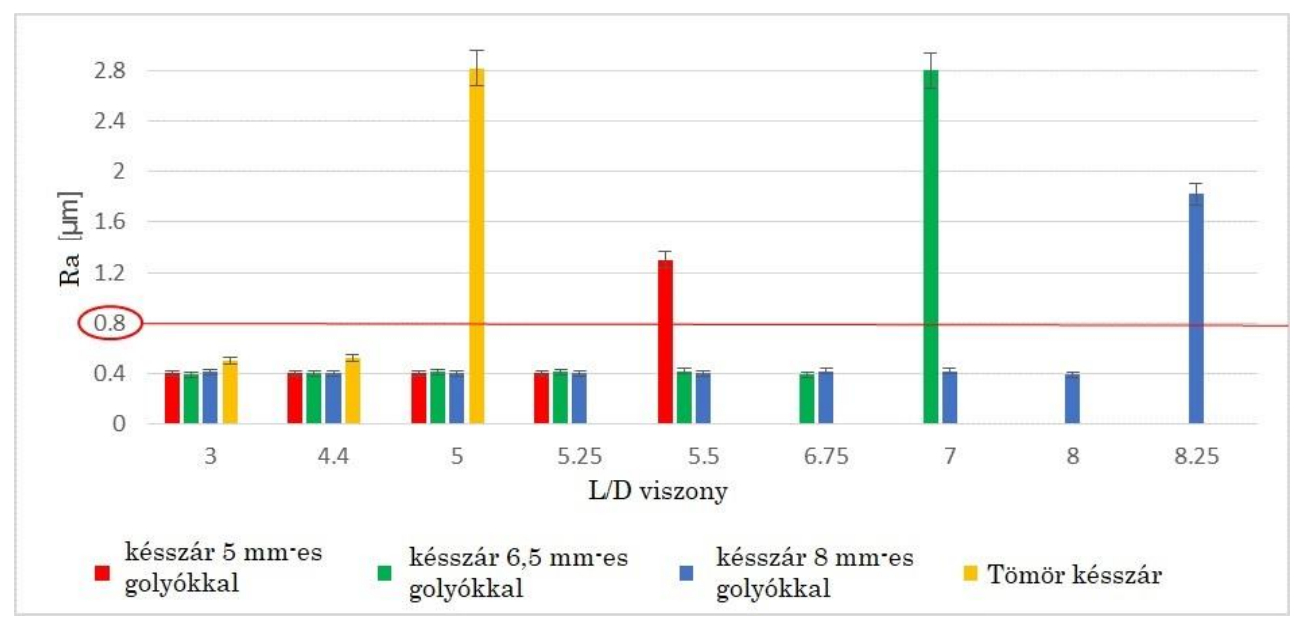

2. ábra. Az edzett acél megmunkált felületi érdessége különbözö típusú csillapitott esztergakések alkalmazásakor, a túlnyúlási értékek függvényében

A jobb megértés érdekében tekintsük a 3. ábrát is, amely a különböző típusú, csillapított esztergakéseken mért gyorsulásjelek RMS értékeit (a forgácsoló élhez közel felragasztott piezoelektromos gyorsulásmérö értékeit) mutatja a különböző $L / D$ túlnyúlási értékek függvényében.

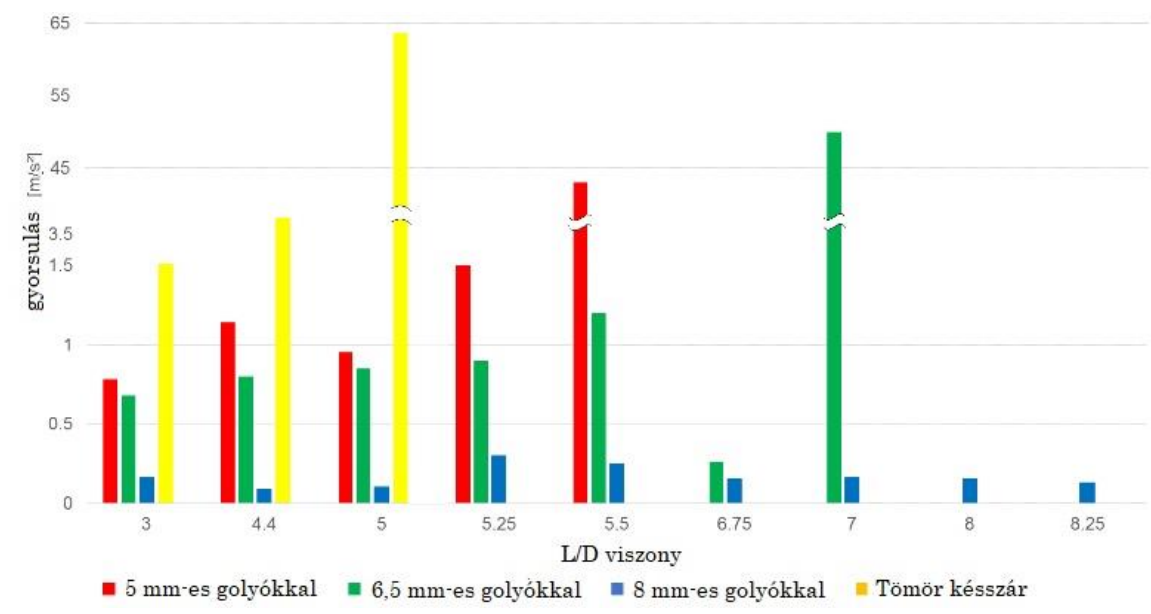

3. ábra. Szerszámrezgések RMS gyorsulás értékei a különbözö típusú csillapitott esztergakések esetén 


\section{3. Összefoglalás, következtetések}

A vizsgálataink során megállapítottuk, hogy a szerszámrezgések közel azonosak maradnak a túlnyúlási értékek növelésével egy bizonyos határértékig. Ezen határérték után hirtelen amplitúdó növekedéssel számolhatunk, amit gyakorlatilag a túlnyúlás felső határértékének / dinamikailag stabil, forgácsleválasztáshoz szükséges felső túlnyúlási határnak tekintünk. A szerszám dinamikailag rendkívül érzékennyé válhat forgácsolás közben; érzékeny a dinamikai paraméterek változtatására, a túlnyúlás felső határának kis környezetében; ennek következtében könnyü belátni, hogy a túlnyúlás mértékére is. Az ütközéses elven müködő csillapítással ellátott furat esztergakés (Impact Damper - ID) növelte a lehetséges túlnyúlás értékét, a dinamikailag stabil forgácsleválasztás mellett, amely lehetővé tette a mély furatok belső megmunkálását. Ahogy a késszár üregében alkalmazott acélgolyók (mint csillapító elemek) átmérőjét növeltük, a túlnyúlás maximális lehetséges értéke is nőtt (jelezve, hogy a nagyobb méretü golyók nagyobb mértékủ csillapítást tesznek lehetővé; a nagyobb méretủ csillapító elemeknek nagyobb a tömege, továbbá az üregben kisebb a rés a fal és a csillapító elemek között, amely növeli az ütközési energia átadásának mértékét). Fontos megemlíteni, hogy a jelen munkánkban alkalmazott legkisebb (5 mm-es) és legnagyobb (8 $\mathrm{mm}$-es) átméröjü acélgolyók között csaknem négyszeres tömegkülönbséget mérhetünk.

\section{Köszönetnyilvánítás}

A cikkben ismertetett kutató munka az EFOP-3.6.1-16-2016-00011 jelü „Fiatalodó és Megújuló Egyetem - Innovatív Tudásváros - a Miskolci Egyetem intelligens szakosodást szolgáló intézményi fejlesztése" projekt részeként - a Széchenyi 2020 keretében - az Európai Unió támogatásával, az Európai Szociális Alap társfinanszírozásával valósul meg.

\section{Irodalom}

[1] Suyama, D.I., Diniz, A.E., Pederiva, R. The use of carbide and particle-damped bars to increase tool overhang in the internal turning of hardened steel. Intern J of Advan Manuf Tech 2016, 86:2083-2092. https://doi.org/10.1007/s00170-015-8328-z

[2] Schneider, G. Cutting tool applications chapter 10: boring operations and machines - American Machinist. Modern Machine Shop, http://www.americanmachinist.com/; 2010 [accessed: 12 February 2017].

[3] Smith, G.T. Cutting Tool Technology: Industrial handbook. Springer-Verlag, Southampton (UK) 2008.

[4] Dimarogonas, A. Vibration for Engineers, 2nd ed. Prentice Hall, Upper Saddle River, New Jersey 1996.

[5] Liu, X., Liu, Q., Wu, S., Liu, L., Gao, H. Research on the performance of damping boring bar with a variable stiffness dynamic vibration absorber. Inter J of Adv Manuf Tech 2017, 89:28932906. https://doi.org/10.1007/s00170-016-9612-2

[6] Bavastri, C.A. Redução de Vibrações de Banda Larga em Estruturas Complexas por Neutralizadores Viscoelásticos (Wide band vibration reduction in complex structures by viscouselastic neutralizers). PhD Thesis, UFSC, Florianópolis Santa Catarina, Brazil 1997.

[7] Sandvik. Silent tool for turning: overcome vibrations in internal turning. http://www.sandvik.coromant.com/en-us/products/silent_tools_turning [accessed: 15 May 2017]. 
[8] Hahn, R.S. Design of Lanchester damper for elimination of metal-cutting chatter. Trans ASME 1951, 73: 3.

[9] Biju, C.V., Shunmugam, M.S. Investigation into effect of particle impact damping (PID) on surface topography in boring operation. Int $\mathbf{J}$ of Adv Manuf Tech 2014, 75:1219-1231. https://doi.org/10.1007/s00170-014-6201-0 